SCIENCE AND HUMANITIES JOURNAL

VOL. 11, 2017, pp. 1-16 DOI: https://doi.org/10.47773/shj.1998.110.1

\title{
LEVELS OF LEAD IN SELECTED COMMON MEDICINAL PLANTS GROWING ALONG ROADSIDE IN LEYTE
}

\author{
HONEYLENE V. ONGY ${ }^{1}$ and BEATRIZ S. BELONIAS ${ }^{1}$ \\ ${ }^{1}$ Department of Biological Sciences, Visayas State University, \\ Visca 6521-A, Baybay City, Leyte, Philippines
}

\begin{abstract}
Lead, as an important environmental pollutant from vehicular emission, is generally the largest source of heavy metal contamination in roadside ecosystems. Ten common Philippine medicinal plants namely: Allium fistulosum, Artemisia vulgaris, Basella alba, Ipomoea batatas, Euphorbia hirta, Plectranthus amboinicus, Mimosa pudica, Cymbopogon citratus, Portulaca oleracea, and Curcuma longa growing along the $45-\mathrm{km}$ stretch of the Baybay - Ormoc national highway were investigated for $\mathrm{Pb}$ accumulation. The study showed Curcuma longa, Plectranthus amboinicus, and Artemisia vulgaris had the highest Pb content in the leaves. In the stem, Mimosa pudica had the lowest with $5.0 \mathrm{mg} / \mathrm{kg}$ while Plectranthu samboinicus had the highest with $9.5 \mathrm{mg} / \mathrm{kg}$. In the roots, $\mathrm{Pb}$ was highest $(18.0 \mathrm{mg} / \mathrm{kg})$ in Allium fistulosum but low (below $10.0 \mathrm{mg} / \mathrm{kg}$ ) in all the other species. Results imply that consumption of medicinal plants growing along busy roads may not be safe, especially those species that accumulate high levels of $\mathrm{Pb}$. Long term usage of these plants may cause serious health problems.
\end{abstract}

Key words: medicinal plant, lead bioaccumulation, permissible limit, health problems

Correspondence : H. V. Ongy. Address: Department of Biological Sciences, College of Arts and Sciences, Visayas State University, Baybay City, Leyte, 6521 - A Philippines. E-mail: honeylene.ongy@vsu.edu.ph 


\section{INTRODUCTION}

Herbal medicines have long been used by Chinese and Western cultures. Today, many drugs are still extracted as fractionate/isolate compounds from raw herbs and purified to meet pharmaceuticals standards (Ahmad and Othman, 2013). Usage of plant materials as a source of medicine for a wide variety of human ailments has increased significantly in the developing nations. Population rise, inadequate supply of drugs, prohibitive cost of treatments, side effects of synthetic drugs and development of resistance to currently used drugs for infectious diseases are some of the reasons why people are switching to medicinal plants (Zahid, 2016).

However, these medicinal plants might grow on soil contaminated with heavy metals from industrial activity, automobile exhaust, municipal wastes, refuse burning and pesticides used in agriculture (Annan et al., 2010). Traffic-associated environmental pollution is one of the most critical or challenging sources, because it is a non-point source and vehicular emissions spread beyond the expected distances polluting the air, land and water bodies (Osakwe and Okolie, 2015).

Plants are the main link in the transfer of heavy metals from contaminated soil to the human body (Ali Khan et al., 2015). Heavy metals like lead enters the plant via root uptake and foliar adsorption. They accumulate over time in the tissues of plants which eventually enter humans through consumption of plant parts and extracts (Kulhari et al., 2013). Consumption of medicinal plants grown in polluted sites is a serious threat to human health.

Ali and Nasralla (1985) suggested that lead accumulates in plants through both foliage and root system, but lead absorption through foliage is more pronounced in locations close to the emission source of lead vapor and fine particles. Sharma and Dubey (2005) reported that plants growing near highways are usually exposed to more lead than in other areas. Ali and Nasralla (1985) reported that vegetables grown adjacent to the busiest streets had elevated levels of $\mathrm{Pb}$ in the leaves and roots. Rolli et al. (2015) found that the soil, grass and Caesalpinia leaves collected from roadsides likewise contained higher levels of lead. This is 
because lead compounds are major pollutants present in vehicular exhaust.

In India and some African countries where most people use medicinal plants for the treatment of a wide range of health-related applications, some studies were done to investigate the potential accumulation of lead and other heavy metals in medicinal plants. Deka et al. (2011), discovered that the amount of $\mathrm{Pb}$ in the 21 medicinal species they studied exceeded the maximum permissible level (MPL) of $\mathrm{Pb}$ in their tissues.

The safety of using medicinal plants grown along highways and well-travelled roads has become a growing concern especially in highly populated areas. Thus, this study was conducted to determine and compare the amounts of lead absorbed by common Philippine medicinal plants growing along potentially lead-contaminated roadsides and to identify which medicinal plant species can tolerate the highest level of lead in their tissues.

\section{MATERIALS AND METHODS}

\section{Study Area}

Samples of medicinal plants commonly used in the province of Leyte were collected along the Baybay - Ormoc highway. Baybay City and Ormoc City are component cities located on the western coast of the Leyte Province. Figure 1 shows the map of the Leyte Province.

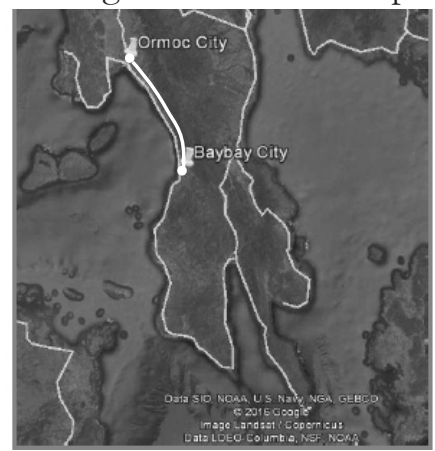

Figure 1.Map of the Leyte Province showing the Baybay Ormoc Highway 


\section{Collection and Preparation of Plant Samples}

Five healthy sample plants of each of species were collected. Only those that were growing within a 3-m distance from the edge of the road were included. The sample plants were placed in clean properlylabeled plastic bags and were transported right away to the laboratory for processing. These were washed thoroughly to remove dirt and pat-dried using tissue paper. Each sample was separated into roots, stems and leaves, placed inside separate brown paper bags and dried in an oven at $70^{\circ} \mathrm{C}$ for 48 hours. The oven-dried plants were ground into fine powder and analyzed for total $\mathrm{Pb}$ using the method of Mylavarapu and Kennelley (2002) at the Central Analytical Services Laboratory (CASL), Visayas State University, Baybay City, Leyte.

\section{Soil Sample Collection}

Soil samples were collected from the sites where the top three medicinal plants with the highest lead content were collected. Samples were collected within the immediate vicinity of the plants at a depth of $0-10 \mathrm{~cm}$ from the surface. The samples were transferred into labeled plastic bags and analyzed at the Central Analytical Services Laboratory (CASL) for total $\mathrm{Pb}, \mathrm{pH}$ and organic matter. Total soil $\mathrm{Pb}$ content was analyzed using the AquaRegia Method (DIN ISO 11466, 1994).

\section{RESULTS AND DISCUSSION}

\section{Description of Study Area}

Ormoc City is considered as the economic, cultural, commercial and transportation hub of western Leyte. The highway is busy with motorized vehicles. There are four industrial plants located along this highway, a copra oil milling facility adjacent to an abaca pulp milling facility operated by the Specialty Pulp Manufacturing, Inc.(SPMI) in Brgy. Hilapnitan, Baybay City, an oil mill by SC Global Coco Products, Inc. in Brgy. Caridad, Baybay City, and a carbon processing plant operated by Green Carbon, Inc. in Brgy. Maybog, Baybay City, Leyte. 
The major terminals in both cities serve routes from Tacloban City, Maasin City, Metro Manila, Davao City and some other major towns in Leyte, Southern Leyte, and Samar provinces. With the increase in population and industries between the two cities, there is a continuing increase in vehicular volume going to and from Baybay to Ormoc. As a result, there is an increase in vehicular exhaust along this major highway and lead toxicity may occur along this part of the province.

\section{Collected Medicinal Plants}

Ten selected medicinal plants growing along the Baybay - Ormoc highway; namely, Allium fistulosum, Artemisia vulgaris, Basella alba, Curcuma longa, Cymbopogon citratus, Euphorbia hirta, Ipomoea batatas, Mimosa pudica, Plectranthus amboinicus and Portulaca oleracea were collected. These species are among the most commonly used medicinal plants in Leyte.

The ten medicinal plants used are presented in Table 1. The acceptable level of lead in the body as defined by WHO (2007) is $10 \mathrm{mg} / \mathrm{kg}$ but this amount can already have an adverse effect to the human body. Lead concentration varies per species and in each plant part.

According to Olowu et al. (2015), the uptake and distribution of trace metals vary from species to species and could be associated with the differences in the ability of the plant to control the movement of trace metals from xylem to phloem and via the phloem to other parts of the plant. Table 2 summarizes the pharmacognostic features of the selected medicinal plants.

Table 1. The ten medicinal plants used in the study

\begin{tabular}{|c|c|c|c|}
\hline SCIENTIFIC NAME & ENGLISH NAME & LOCAL NAME & FAMILY NAME \\
\hline Allium fistulosum $\mathrm{L}$. & Spring onion & Sibuyas dahon & Amaryllidaceae \\
\hline Artemisia vulgaris $\mathrm{L}$. & Mugwort & $\begin{array}{l}\text { Hilbas } \\
\text { Damong maria }\end{array}$ & Asteraceae \\
\hline Basella alba L. & Spinach vine & Alugbati & Basellaceae \\
\hline Curcuma longa $\mathrm{L}$. & Turmeric & Duwaw & Zingiberaceae \\
\hline Cymbopogon citratus (DC.) Staph & Lemon grass & Tanglad & Poaceae \\
\hline Euphorbia birta L. & Asthma weed & $\begin{array}{l}\text { Tawa -tawa } \\
\text { Gatas -gatas }\end{array}$ & Euphorbiaceae \\
\hline Ipomoea batatas (L.) Lam. & Sweet potato & Kamote & Convulvolaceae \\
\hline Mimosa pudica L. & Sensitive plant & Makahia & Fabaceae \\
\hline Plectranthus amboinicus $\mathrm{L}$. & Oregano & $\begin{array}{l}\text { Carabo } \\
\text { Oregano }\end{array}$ & Lamiaceae \\
\hline Portulaca oleracea L. & Pigweed, Purslane & Olasiman & Portulacaceae \\
\hline
\end{tabular}


Table 2. Pharmacognostic features of the ten medicinal plants studied

\begin{tabular}{|c|c|c|c|}
\hline SCIENTIFIC NAME & REFERENCE & $\begin{array}{l}\text { PARTS } \\
\text { UTILIZED }\end{array}$ & MEDICINAL USE \\
\hline Allium fistulosum $\mathrm{L}$. & Fern (2014) & Leaves, bulb & $\begin{array}{l}\text { For treatment of colds, abdominal } \\
\text { coldness and fullness, impending } \\
\text { internal parasites. Externally, the bulb } \\
\text { can be made into a poultice to drain } \\
\text { pus from sores, boils and abscesses. }\end{array}$ \\
\hline Artemisia vulgaris $\mathrm{L}$. & Stuart (2015) & $\begin{array}{l}\text { Leaves and } \\
\text { flowers }\end{array}$ & $\begin{array}{l}\text { Used as expectorant, induce } \\
\text { menstruation, for asthma, dyspepsia, } \\
\text { and intestinal deworming. }\end{array}$ \\
\hline Basella alba $\mathrm{L}$. & Roshan et al. (2012) & Leaves, sap & $\begin{array}{l}\text { Treatment of hypertension, malaria̧ } \\
\text { and anemia. Reported to have } \\
\text { antifungal, anticonvulsant, analgesic, } \\
\text { anti-inflammatory properties. }\end{array}$ \\
\hline Curcuma longa $\mathrm{L}$. & Krup et al. (2013) & Whole plant & $\begin{array}{l}\text { Remedy for cough, diabetes and } \\
\text { hepatic disorders. }\end{array}$ \\
\hline $\begin{array}{l}\text { Cymbopogon citratus } \\
\text { (DC.) Staph }\end{array}$ & $\begin{array}{l}\text { http://tanimnicharls } \\
\text { e.blogspot.com/p/us } \\
\text { es-of-herbal.html }\end{array}$ & Whole plant & $\begin{array}{l}\text { Used to aid digestion, stomach } \\
\text { problems, toothache, sprain, vomiting, } \\
\text { ringworm, and to reduce fevers. }\end{array}$ \\
\hline $\begin{array}{l}\text { Euphorbia hirta (L.) } \\
\text { Lam. }\end{array}$ & Stuart (2017) & Whole plant & $\begin{array}{l}\text { Used to treat asthma, coughs, } \\
\text { diarrhea, dysentery, and dengue fever. }\end{array}$ \\
\hline Ipomoea batatas $\mathrm{L}$. & Stuart (2015) & $\begin{array}{l}\text { Tops, leaves and } \\
\text { edible roots }\end{array}$ & $\begin{array}{l}\text { Tops, used for diabetes. } \\
\text { Crushed leaves applied to boils and } \\
\text { acne. } \\
\text { Boiled roots used for } \\
\text { diarrhea. Reports of improved } \\
\text { platelet counts on denguepatients } \\
\text { drinking decoction ofsweetpotato } \\
\text { tops. }\end{array}$ \\
\hline Mimosa pudica $\mathrm{L}$. & Stuart (2017) & Whole plant & $\begin{array}{l}\text { Roots used as diuretic, for dysentery } \\
\text { and dysmenorrhea. Entire plant in } \\
\text { decoction used as antiasthmatic. }\end{array}$ \\
\hline Plectranthus amboinicus $\mathrm{L}$. & Roshan et al. (2010) & Leaves & $\begin{array}{l}\text { Useful in cephalalgia, otalgia, } \\
\text { anorexia, dyspepsia, flatulence, colic, } \\
\text { diarrhea, and cholera especially in } \\
\text { children, halitosis, convulsions, } \\
\text { epilepsy, cough, chronic asthma, } \\
\text { hiccough, bochitis, renal and vesical } \\
\text { calculi, strangury, hepatopathy, } \\
\text { malarial fever, antispasmodiç and } \\
\text { cathartic. }\end{array}$ \\
\hline Portulaca oleracea $\mathrm{L}$. & Eaqub et al. (2014) & Whole plant & $\begin{array}{l}\text { Used for treatment of burnsand } \\
\text { diseases related to the intestine, liver, } \\
\text { stomach, cough, shortness of breath, } \\
\text { and arthritis. Its use as a purgative, } \\
\text { cardiac tonic, emollient, muscle } \\
\text { relaxant, and antinflammatory. }\end{array}$ \\
\hline
\end{tabular}




\section{$\mathrm{Pb}$ Concentrations in the Collected Medicinal Plants}

Results of $\mathrm{Pb}$ analysis in the leaves, stems, and roots of the ten collected medicinal plants are summarized in Figure 2. In general, higher levels of lead were found in the leaves compared to the stems and roots of all the medicinal plants studied except for $A$. fistulosum.

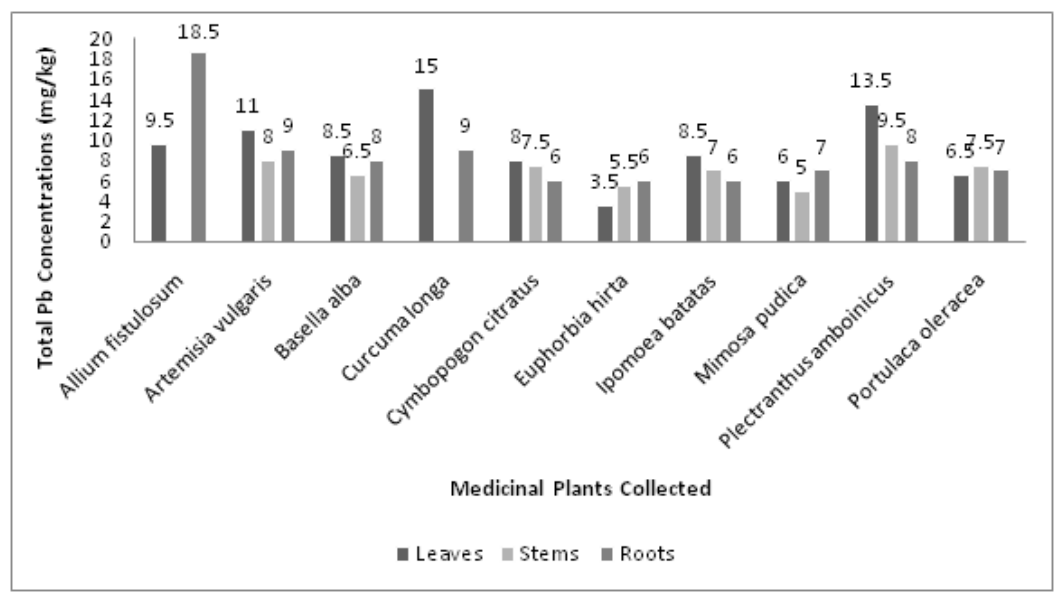

Figure 2. Lead concentrations $(\mathrm{mg} / \mathrm{kg})$ in the leaves, stems and roots of the ten collected medicinal plants

Lead concentrations in the leaf samples ranged from $3.5 \mathrm{mg} / \mathrm{kg}$ in E. hirta to $15.0 \mathrm{mg} / \mathrm{kg}$ in C. longa. Pb concentrations in A. vulgaris (11.0 $\mathrm{mg} / \mathrm{kg}$ ) and $P$. amboinicus $(13.5 \mathrm{mg} / \mathrm{kg})$ also exceeded the permissible limit of $10 \mathrm{mg} / \mathrm{kg}$ set by the World Health Organization if consumed. Jankowski et al. (2015) mentioned that the plant's diverse ability to accumulate heavy metals in the above ground parts (leaves and stems) is due to the different morphological features of these parts like surfaces covered with plant hairs, wrinkles, a spongy or stubbly structure, leaf size and leaf orientation. Fine hairs and the lobes in the leaf margins of $A$. vulgaris and $P$. amboinicus possibly help in trapping lead particles in the leaf surface while the large surface area of $C$. longa leaves may have provided a greater collection opportunity for lead atmospheric fall out.

A. vulgaris and $P$. amboinicus accumulated the highest levels of $\mathrm{Pb}$ 
concentration in the stems $(8 \mathrm{mg} / \mathrm{kg}$ and $9.5 \mathrm{mg} / \mathrm{kg}$, respectively). According to Rossi (2008), a blood lead level of $10.0 \mathrm{mg} / \mathrm{kg}$ is the current threshold for lead toxicity as adopted by the United States (US) Centers for Disease Control and Prevention (CDC) in 1991 and the World Health Organization in 1995 but blood lead levels below this concentration have substantial public health impact on children and are apparently longlasting and irreversible. Though $\mathrm{Pb}$ content in $A$. vulgaris and $P$. amboinicus stems were below $10.0 \mathrm{mg} / \mathrm{kg}$, continuous exposure may result in chronic illnesses as lead accumulates in the body. In the roots or underground biomass, maximum amount of $\mathrm{Pb}$ was found in $A$. fistulosum $(18.5 \mathrm{mg} / \mathrm{kg})$. All the other plant samples have $\mathrm{Pb}$ concentrations below the permissible limit. A. fistulosum is a very common ingredient in Asian cuisine but the root is not usually used in cooking.

Of the 10 species, C. longa, P. amboinicus and A. vulgaris had lead concentrations in the leaves that were greater than $10 \mathrm{mg} / \mathrm{kg}$. All parts of these plants are used for medicinal purposes and are used in a variety of ailments. All parts had $\mathrm{Pb}$ concentrations above or near the permissible limit. These plants are widely cultivated and often established around houses and gardens.

For $A$. vulgaris, leaves, flowers and roots are the parts particularly used for medicinal purposes (Grieve, 1971). A decoction of fresh or dry leaves is usually given to treat asthma, abdominal pains, intestinal deworming and to induce menstruation (Stuart, 2015). Studies conducted by Ostrowska and Porebska (1999), Alirzayeva et al. (2006) and Dalvanda et al. (2014) showed that species of Artemisia can be used for the phytoremediation of polluted soils and air.

Leaves of C. longa is commonly used in the Philippines to add aroma and flavor to chicken or pork soup. The rhizome is used as a yellow powder which is used as a flavoring in many cuisines and as a medicine to treat many diseases like flatulence, jaundice, menstrual difficulties, hematuria, hemorrhage, and applied as an ointment to treat many skin diseases (Unissa et al., 2014).

P. amboinicus, an aromatic herb, is tolerant to a wide range of lead concentrations and nutrient deficiency (Arunbabu et al., 2014). 


\section{Soil Properties}

According to Dumat et al. (2011), the behavior of lead in soil and its uptake by plants is controlled by its speciation and soil $\mathrm{pH}$, soil particle size, cation-exchange capacity, root surface area, root exudation, and degree of mycorrhizal transpiration.

Soil samples were collected from the sites where the top three highest $\mathrm{Pb}$ accumulators were growing. As shown in Table 3, all three sites have $\mathrm{pH}$ close to 7.0, with Brgy. Gabas having the lowest $\mathrm{pH}$ of 5.41 . Under acidic condition, heavy metals are more mobile and become more available below ground and vertically upward for plant uptake (Nazareno et al., 2011).

Table 3. Soil properties of the soil samples collected from where the top three

$\mathrm{Pb}$ accumulator medicinal plants were growing

\begin{tabular}{llccc}
\hline $\begin{array}{c}\text { MEDICINAL PLANT } \\
\text { GROWING }\end{array}$ & \multicolumn{1}{c}{ LOCATION } & $\mathrm{pH}$ & OM (\%) & $\begin{array}{c}\mathrm{Pb} \\
(\mathrm{mg} / \mathrm{kg})\end{array}$ \\
\hline Artemesia vulgaris & $\begin{array}{l}\text { Brgy. Sta. Cruz, Baybay } \\
\text { City, Leyte }\end{array}$ & 6.86 & 0.82 & 3.75 \\
Curcuma longa & $\begin{array}{l}\text { Brgy. Candadam, } \\
\text { Baybay City, Leyte }\end{array}$ & 6.57 & 3.69 & 7.10 \\
Plectranthus amboinicus & $\begin{array}{l}\text { Brgy. Gabas, Baybay } \\
\text { City, Leyte }\end{array}$ & 5.41 & 12.48 & 18.85 \\
\hline
\end{tabular}

P. amboinicus in Brgy. Gabas was growing outside a rice mill and forming a very dense cluster. Figure 3 a shows the cluster of $P$. amboinicus growing along the road in Brgy. Gabas, Baybay City, Leyte. The density of the plant with plenty of leaf litter in the ground and evidence of rice hull added to the soil could explain the high OM content of $12.48 \%$, which was the highest among the three locations. The high $\mathrm{Pb}$ level of $18.85 \mathrm{mg} / \mathrm{kg}$ in the soil where P. amboinicus was growing could be due to its constant exposure to vehicular exhaust coming from the many big trucks going in and out of the compound. 
A. vulgaris collected along the road in Brgy. Sta. Cruz, Baybay City, Leyte was growing on sandy soil. The plants were not forming dense clusters and had little leaf litter (Fig. 3b). These could explain the small $\mathrm{OM}(0.816 \%)$ in the soil. Pb level was the least among the three sites.

C. longa was growing outside a welding shop in Brgy. Candadam, Baybay City, Leyte. The extracted soil $\mathrm{Pb}$ was $7.10 \mathrm{mg} / \mathrm{kg}$. Although the soil has been exposed to possible lead pollution from the nearby welding shop, the shop had just opened for less than a year. Duration of exposure is one of the factors in bioaccumulation. Most exposures to chemicals in the environment vary continually in concentration and duration (Bioaccumulation, 1993). Figure 3c shows C. longa planted in pots along the road.
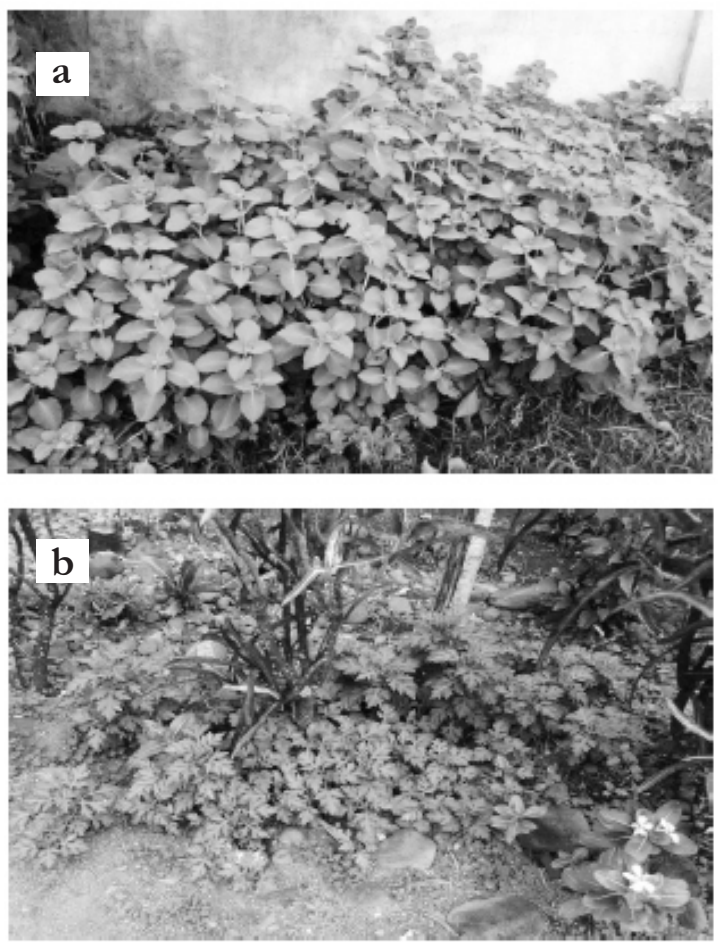


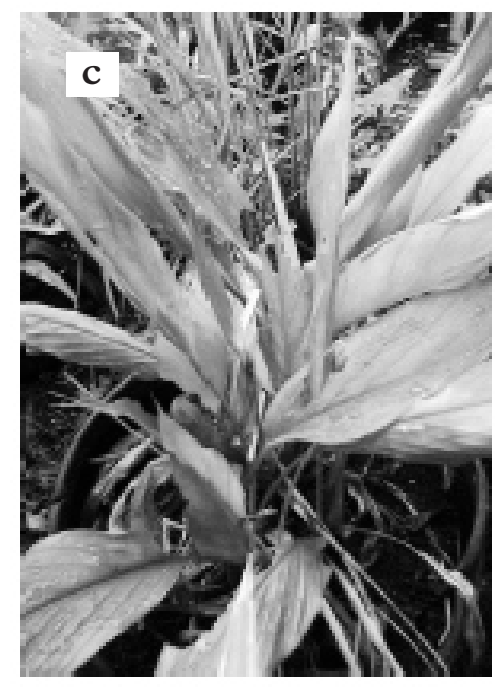

Figure 3. Plectranthus amboinicus (a), Curcuma longa (b), and Artemisia vulgaris (c) growing along the Baybay-Ormoc Highway

\section{CONCLUSION AND RECOMMENDATIONS}

Curcuma longa, Plectranthus amboinicus, and Artemisia vulgaris can accumulate high $\mathrm{Pb}$ concentrations in the leaves. The $\mathrm{Pb}$ levels in the leaves exceeded the permissible limit of $10 \mathrm{mg} / \mathrm{kg}$ set by the World Health Organization (WHO). In the stem, Mimosa pudica had the lowest with $5.0 \mathrm{mg} / \mathrm{kg}$ while Plectranthus amboinicus had the highest with 9.5 $\mathrm{mg} / \mathrm{kg}$. In the roots, $\mathrm{Pb}$ was highest $(18.0 \mathrm{mg} / \mathrm{kg})$ in Allium fistulosum. All the other plants had $\mathrm{Pb}$ levels below $10.0 \mathrm{mg} / \mathrm{kg}$ in the roots. This could mean that the aforementioned plants are potential $\mathrm{Pb}$ bioaccumulators. Therefore, caution should be taken when collecting or growing these medicinal plants. To ensure their safe use, these plants should not be collected nor planted along busy streets due to their ability to accumulate high levels of $\mathrm{Pb}$ mostly from vehicular exhaust. Long term usage and consumption of large quantities of $\mathrm{Pb}$-contaminated plants may lead to increased blood $\mathrm{Pb}$ levels resulting to serious health problems.' 


\section{LITERATURE CITED}

Ahmad, S. and N. Othman. 2013. Strategic Planning, Issues, Prospects and the Future of the Malaysian Herbal Industry. International Journal of Academic Research in Accounting, Finance and Management Sciences. 3(4): pp. 91-102. doi: 10.6007/IJARAFMS/v3-i4/310.

Ali, E.A. and M.M. Nasralla. 1985. Lead accumulation in edible portions of crops grown near Egyptian traffic roads. Agriculture, Ecosystems and Environment. 13(1): $73-82$

Ali Khan, M., S. Al Khatib, R. Dghaim and H. Rasool. 2015. Determination of heavy metal concentration in traditional herbs commonly consumed in the United Arab Emirates. Journal of Environmental and Public Health. 2015: 6

Alirzayeva, E. G., V.M. Ali-zade, S.M. Alverdiyeva, I. Cakmak, L. Ozturk, T.S. Shirvani, E.S Shukurov and M.A. Yazici. 2006. Heavy metal accumulation in Artemisia and foliaceous lichen species from the Azerbaijan flora. For. Snow Landsc. Res. 80(3):339-348

Annan K., A.I. Kojo, A. Cindy, A.N. Samuel, and B.M. Tunkumgnen. 2010. Profile of heavy metals in some medicinal plants from Ghana commonly used as components of herbal formulations. Pharmacognosy Research. 2010 (2): 41-4

Arunbabu, V., A. Ignatius, J. Neethu and E.V. Ramasamy. 2014. Rhizofiltration of lead using an aromatic medicinal plant Plectranthus amboinicus cultured in a hydroponicnutrient film technique (NFT) system. Environ Sci.Pollut. Res.Int.21(22):13007-16.doi: 10.1007/s11356-014-3204-1.

Bioaccumulation. 1993. Extension Toxicology Network. Retrieved from http:/ / extoxnet.orst.edu/tibs/bioaccum.htm on May 11, 2017

Dalvanda, M., M.A. Zare Chahookib, A.H. Hamidiana, S.A.A. Mirjalilid, E. Esmaeil Zadee and B. Moteshare Zadehc. 2014. Comparing 
heavy metal accumulation abilities in Artemisia aucheri and Astragalus gummifer in Darreh Zereshk region, Taft. 19(2): 137-140

Deka, H., S. Deka, R.r. Saikia and H. Serma. 2011. Accumulation of heavy metals in selected medicinal plants. Rev. Environ. Contam. Toxicol. 214: 63-86

Din Iso 11466. 1994. Leaching of soil and sediment samples by aqua regia determination of heavy metals by $A A S$

Dumat, C., E. Pinelli, B. Pourrut, M. Shahid and P. Winterton. 2011. Lead uptake, toxicity, and detoxification in plants. Rev. Environ. Contam. Toxicol. 213:113-36

Eaqub A., M.S. Hossain, A.S. Juraimi, M.M. Rahman, A. Un Nahar and K. Uddin. 2014. Purslane Weed (Portulacaoleracea): A Prospective Plant Source of Nutrition, Omega-3 Fatty Acid, and Antioxidant Attributes. Scientific World Journal. 2014: 951019. doi: 10.1155/2014/951019.

Fern, K. 2014. Useful Tropical Plants. Retrieved from http://tropical.theferns.info/viewtropical.php?id=Allium + fist ulosum on April 30, 2017

Grieve, M. 1971. A Modern Herbal. Retrieved from http://www.botanical.com/botanical/mgmh/m/mugwor61.ht ml on April 30, 2017

Herbal/medicinal Plants, nd. Retrieved from http://tanimnicharlse.blogspot.com/p/uses-of-herbal.html on March 12, 2017

Krup V., L.H. Prakash and A. Harini. 2013. Pharmacological activities of turmeric (Curcuma longa Linn): A Review. Journal of Traditional Medicine and Clinical Naturopathy. 2:133.

Kulhari, A., A. Sheorayan, S. Bajar, S. Sarkar, A. Chaudhury and R.K. 
Kalia. 2013. Investigation of heavy metals in frequently utilized medicinal plants collected from environmentally diverse locations of north western India. 2: 676

Leyte Map. 2017. Maplandia.com. Retrieved from http://www.maplandia.com/ philippines/region8/leyte/leyte/ on June 1,2017

Mylavarapu, R.S. and E.D. Kennelley. 2002.Analytical Procedures and Training Manual. UF/IFAS Extension Soil Testing Laboratory (ESTL), Department of Soil and Water Science, Florida Cooperative Extension Service, Institute of Food and Agricultural Sciences, University of Florida, Gainesville, FL 32160

Nazareno, P.G., I.E. Buot and M.E. Flavier. 2011. The plants in a landfill in the Philippines and their behavior towards lead and mercury: Their potential use for future remediation of metalcontaminated soils in the country. Journal of Environmental Science and Management. 14(1): 60-70

Olowu, R.A., G.O. Adewuyi, O.J. Onipede, O.A. Lawal, and O.M. Sunday. 2015. Concentration of heavy metals in root, stem and leaves of Acalyphaindica and Panicum maximum Jacq from three major dumpsites in Ibadan Metropolis, South West Nigeria, American Journal of Chemistry. 5(1): pp. 40-48.

Osakwe, S.A. and L.P. Okolie. 2015. Physicochemical characteristics and heavy metals contents in soils and cassava plants from farmlands along a major highway in Delta State, Nigeria. J. Appl. Sci. Environ. Management.19(4): 695-704

Ostrowska, A. and G. Porębska. 1999. Heavy metal accumulation in wild plants: Implications for phytoremediation. Polish Journal of Environmental Studies. 8(6): 433-442 
Rolli N.M., B.I. Karalatti and S.B. Gadi. 2015. Metal accumulation profile in roadside soils, grass and Caesalpinia plant Leaves: Bioindicators. J. Environ. Anal.Toxicol.5:319. doi:10.4172/21610525.1000319

Roshan P., M. Naveen, P.S. Manjul, A. Gulzar, S. Anita and S. Sudarshan. 2010. Plectranthus amboinicus(Lour.) Spreng: An Overview. The Pharma Research. 4;01-15

Roshan Adhikari, H.N. Naveen Kumar and S.D. Shruthi. 2012. A Review on medicinal importance of Basella alba L. International Journal of Pharmaceutical Sciences and Drug Research. 4(2): 110-114

Rossi, E. 2008. Low level environmental lead exposure - A continuing challenge. ClinBiochem Rev, 29(2): 63 - 70

Sharma, P. and R. Dubey. 2005. Lead toxicity in plants. Braz: J. of Plant Physiol. 17 (1): 35-52

Stuart, G. U. 2015 . Philippine Medicinal Plants. http://www.stuartxchange.org/Damong.html. Accessed March 12,2017

Stuart, G. U. 2017 . Philippine Medicinal Plants. http://www.stuartxchange.org/GatasGatas.html. Accessed March 12, 2017

Stuart, G. U. 2015. Philippine Medicinal Plants. http://www.stuartxchange.org/Kamote.html. Accessed March 12,2017

Stuart, G. U. 2017. Philippine Medicinal Plants. http://www.stuartxchange.org/Makahiya.html. Accessed March 12, 2017 
Unissa, S.A., C. Venkateshwar and D. Vineeth. 2014. Treatment of Curcuma longa (turmeric) contaminated with heavy metals. World Journal of Pharmacentical Research. 3 (9): 460-468.

World Health Organization. 2007. Health risks of heavy metals from long-range transboundary air pollution. Copenhagen, Denmark. 144pp

Zahid, M. 2016. Introduction and Importance of Medicinal Plants and Herbs. National Health Portal. Retrieved from https://www.nhp.gov.in/introduction-and-importance-ofmedicinal-plants-and-herbs_mtl on May 2017 